\title{
Vertebrobasilar dolichoectasia with typical radiological features
}

\author{
Surya Nandan Prasad (D, ,' Vivek Singh (D) ,' Vignesh Selvamurugan (D) ,' \\ Rajendra Vishnu Phadke ${ }^{2}$
}

${ }^{1}$ Radiodiagnosis, Sanjay Gandhi Post Graduate Institute of Medical Sciences, Lucknow, Uttar Pradesh, India ${ }^{2}$ Radiology, Apollomedics Super Speciality Hospital, Lucknow, Uttar Pradesh, India

Correspondence to Dr Vivek Singh: singhvivek79@rediffmail.com

Accepted 27 January 2021

Check for updates

(c) BMJ Publishing Group Limited 2021. No commercial re-use. See rights and permissions. Published by BMJ.

To cite: Prasad SN, Singh V, Selvamurugan $\mathrm{V}$, et al. BMJ Case Rep 2021:14:e239866. doi:10.1136/bcr-2020239866

\section{DESCRIPTION}

A 55-year-old man presented with three episodes of transient loss of consciousness in last 1 month. $\mathrm{He}$ was a known hypertensive, on regular medication. He underwent a full neurological and cardiac workup, including electrocardiography, echocardiography and neck vessels Doppler. His serum lipid profile was within normal limit. Workup with contrast-enhanced CT and CT angiography showed dilated and tortuous distal left vertebral and proximal and mid basilar artery in prepontine and premedullary cisterns (figure 1). The dilated tortuous artery was indenting over anterior surface of left half of pons. V4 segment of right vertebral artery was elongated and crossing the midline to join opposite vertebral artery. Based on these radiological findings, diagnosis of vertebrobasilar dolichoectasia (VBD) was made.

Dolichoectasia (dolichos=long; ectasia $=$ distended) is an uncommon progressive arteriopathy primarily affecting intracranial posterior circulation. VBD is characterised by dilated elongated and tortuous vertebrobasilar arteries. ${ }^{1-3}$ Exact aetiology is unknown, however, it is seen in association with several other diseases like atherosclerosis, hypertension, collagen vascular disease, polycystic kidney disease and sickle cell anaemia. ${ }^{12}$ An imbalance between matrix metalloproteinases and antiprotease activity within the connective tissue of arterial wall leading to aberrant vascular remodelling and defective connective tissue formation within the wall of arteries is thought to be causative mechanism in development of this disease. ${ }^{1}$ VBD is diagnosed incidentally in most of the cases. Symptomatic patients may present either with vascular symptoms like episodes of transient ischaemic attacks, ischaemic strokes, subarachnoid haemorrhages or with compressive symptoms related to brainstem or cranial nerve compression. Sometimes the patient may present with even hydrocephalous. ${ }^{2}$ Traditionally conventional angiography is considered gold standard, however, diagnosis can be made confidently on CT angiography or magnetic resonance angiography. Other associated features like aneurysm formation, presence of intraluminal thrombus or calcification, brain parenchymal changes and relation of dolichoectatic artery with brainstem and cranial nerves can be well assessed on CT and MR images. Basilar artery is considered ectatic when it measures $>4.5 \mathrm{~mm}$ at mid pons level. ${ }^{1-3}$ In cases of VBD, elongation of the artery is quantified based on the level of basilar bifurcation. Normally the basilar bifurcation is below the

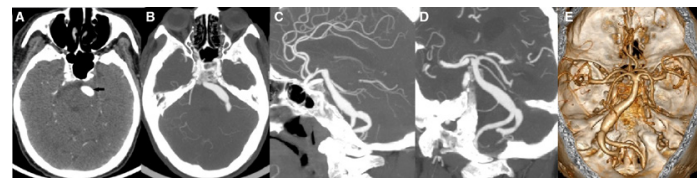

Figure 1 (A) CT angiography image in axial plane at the level of pons shows dilated basilar artery (arrow) in prepontine cistern, indenting over anterior surface of pons on left side. Maximum intensity projection thick slice images in axial (B), sagittal (C) and coronal (D) planes showing dilated tortuous V4 segment of left vertebral artery and proximal and mid basilar artery with high basilar bifurcation at the level of suprasellar cistern. Right vertebral artery is elongated and crossing the midline to join opposite vertebral artery. (E) volume rendered images (seen from above) of CT angiography showing vertebra-basilar dolichoectasia.

level of dorsum sellae while in VBD it may be in suprasellar cistern or even at the level of floor of third ventricle. ${ }^{1}$ The differential diagnosis includes fusiform aneurysm, where the dilatation is focal and circumferential. Whereas in dolichoectasia, the involved arteries are elongated and tortuous with a uniformly enlarged circumference.

At present, there is no universally accepted effective treatment for VBD. ${ }^{1}$ High risk of morbidity and

Learning points

- Vertebrobasilar dolichoectasia is uncommon progressive disease characterised by dilated, elongated, tortuous vertebrobasilar artery and diagnosed on $\mathrm{CT}$ angiography or MR angiography.

- Patients may present with symptoms related to vascular events or compression of brainstem/ cranial nerves by ectatic tortuous vessel. They should undergo complete neurological and cardiac evaluation and other causes should be ruled out before attributing the symptoms to this entity. The workup studies should also include long-time Holter electrocardiography and electroencephalogram in cases where the patient's symptoms are recurrent and not resolved.

- At present, there is no universally accepted effective treatment and surgery is associated with high morbidity and mortality. Endovascular flow diverter/stent placement with or without coiling may be effective in selected patients. 
mortality is associated with surgical interventions as vertebrobasilar artery supplies critical posterior fossa structures besides giving perforators to brainstem. Endovascular flow diverter/ stent placement with or without coiling have been attempted with some success compared with surgery. ${ }^{1}$ Medical management for ischaemic symptoms includes anticoagulation and antiplatelet therapy. For neurovascular compressive symptoms, surgical microvascular decompression performed by interposing synthetic implant between the ectatic artery and the compressed nerve is found safe and effective.

Contributors RVP and SNNP conceived the manuscript. SNNP prepared the manuscript. VSi collected the images and also helped in manuscript preparation. RVP and VSe edited the manuscript. The final manuscript was read and approved by all the authors.

Funding The authors have not declared a specific grant for this research from any funding agency in the public, commercial or not-for-profit sectors.
Competing interests None declared.

Patient consent for publication Obtained.

Provenance and peer review Not commissioned; externally peer reviewed.

\section{ORCID iDs}

Surya Nandan Prasad http://orcid.org/0000-0002-2879-8486

Vivek Singh http://orcid.org/0000-0001-7049-3582

Vignesh Selvamurugan http://orcid.org/0000-0001-7049-3582

\section{REFERENCES}

1 Samim M, Goldstein A, Schindler J, et al. Multimodality imaging of vertebrobasilar dolichoectasia: clinical presentations and imaging spectrum. Radiographics 2016:36:1129-46.

2 Passero SG, Rossi S. Natural history of vertebrobasilar dolichoectasia. Neurology 2008;70:66-72.

3 Wang F, Hu X-Y, Wang T, et al. Clinical and imaging features of vertebrobasilar dolichoectasia combined with posterior circulation infarction: a retrospective case series study. Medicine 2018;97:e13166.

Copyright 2021 BMJ Publishing Group. All rights reserved. For permission to reuse any of this content visit

https://www.bmj.com/company/products-services/rights-and-licensing/permissions/

BMJ Case Report Fellows may re-use this article for personal use and teaching without any further permission.

Become a Fellow of BMJ Case Reports today and you can:

- Submit as many cases as you like

- Enjoy fast sympathetic peer review and rapid publication of accepted articles

- Access all the published articles

Re-use any of the published material for personal use and teaching without further permission

\section{Customer Service}

If you have any further queries about your subscription, please contact our customer services team on +44 (0) 2071111105 or via email at support@bmj.com.

Visit casereports.bmj.com for more articles like this and to become a Fellow 